\title{
A Grande
}

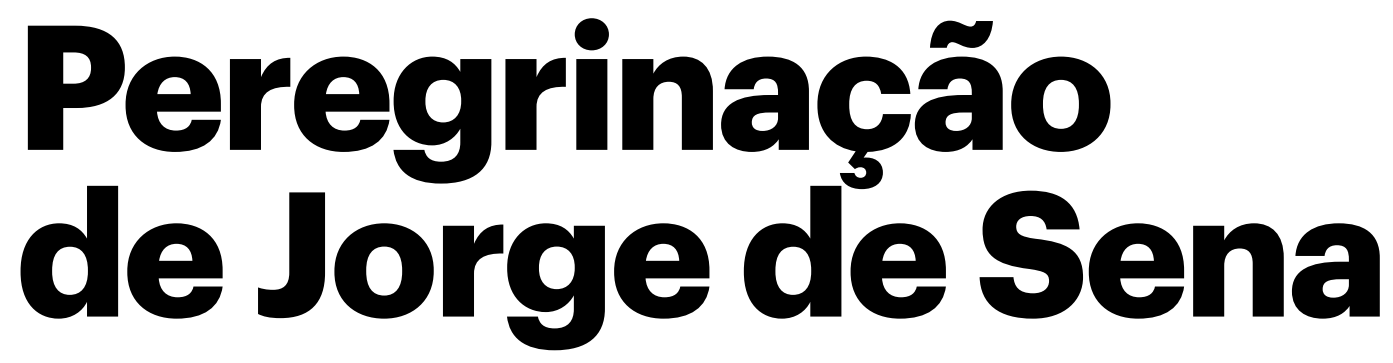

Kenneth David Jackson

Yale University

-k.jackson@yale.edu

Dol https://doi.org/10.34913/

journals/lingualugar.2020.e423 
Estudo do desenvolvimento literário e estético do escritor português Jorge de Sena (1919-1978), antes e durante o seu prolongado exílio. Com notável versatilidade artística e intelectual, meditava sobre o destino humano na sua poesia, enquanto se nutria de sonhos de liberdade, apoiados pela lição universal de obras mestres de arquitetura, arte e música. Como exilado político, nunca parou de dirigir duras críticas e sátiras à sociedade e política salazarista. Vivia sempre com a consciência de uma condição permanente fora de Portugal, redimida pela grandeza de sua obra e seu pensamento.

Palavras-chave: Poesia; exílio; protesto; sátira; viagem; música.

Étude du développement littéraire et esthétique de l'écrivain portugais Jorge de Sena (1919-1978), avant et après son exil prolongé. Avec une remarquable versatilité artistique et intellectuelle, il méditait sur la destinée humaine dans sa poésie, nourrissant des rêves de liberté soutenus par les leçons universelles d'œuvres de grandes maîtres dans l'architecture, l'art et la musique. Exilé politique, il n'a jamais cessé de faire des critiques graves de la société et de la politique salazariste. Il vivait toujours avec la conscience d'une condition permanente en dehors du Portugal, rachetée par la grandeur de son œuvre et de sa pensée.

Mots-clefs: Poésie; exil; protestation; satire; voyage; musique. 
... a libertação nacional é

necessariamente um ato de cultura

- Amílcar Cabral

La mémoire se décline toujours au présent...

- Enzo Traverso

... [...] falareis de nós - de nós! - como de um sonho

- Jorge de Sena "Ode para o Futuro" (Poesia-1, p. 141)

Jorge de Sena interessava-se sempre e avidamente pela literatura. A partir do volume Perseguição (1942), os primeiros livros de poesia seguiram a orientação do movimento neorrealista do Novo Cancioneiro dos anos 1940, mesmo com temas expressivos de Eros, amor e morte, metamorfose e o desconcerto neobarroco da solidão. $O$ ensaísta António Carlos Cortez observa nas décadas de poesia seniana "uma das mais profundas visões sobre a existência que em língua portuguesa (e mesmo noutras línguas) se escreveram" (Cortez, 2019). Na sua poesia, a vida é música estranha acompanhada por palavras ocultas. Escreve Sena, "Eu toco a realidade sem acreditar nela" (Sobre Esta Praia, p. 86). Desde cedo, Sena seguia de perto os poetas vanguardistas franceses e viajou à Inglaterra para entrevistar Edith Sitwell, entre outros poetas do modernismo inglês, a quem dedicou o poema "Meditation in King's Road." Escreveria a seguir uma história dessa literatura, A literatura inglesa, com capítulos notáveis sobre Shakespeare e o vanguardismo, obra negligenciada que é indicador importante do seu desenvolvimento literário e estético (A Literatura Inglesa: Ensaio de Interpretação e de História, 1963).

\section{As primeiras atividades literárias}

A poesia escrita em Portugal depois de Perseguição (1942) inclui mais quatro coleções, Coroa da Terra (1946), Pedra Filosofal (1950), As Evidências (1955) e Fidelidade (1958). Nesses livros, JS questiona princípios universais da moral - pureza, unidade, felicidade, eternidade, fidelidade - dando início a uma corrente de poesia filosófica e de inves- 
tigação da vida, questionando seus motivos e significados universais e a finalidade do poeta no mundo. O estudioso Jorge Vaz de Carvalho encontra na poesia "(...) a expressão maior de uma inteligência sensível à apreensão e transformação estética do seu testemunho da realidade histórica, bem como das dinâmicas culturais da Humanidade, ou, nas palavras do escritor, 'uma meditação sobre o destino humano e no facto de criar linguagem'” (Carvalho, 2019).

Esses primeiros livros incluem poemas conhecidos de sátira social, na forma de paródias, como "Paraísos artificiais:" "Na minha terra, não há terra, há ruas / A minha terra não é inefável / A vida na minha terra é que é inefável / Inefável é o que não pode ser dito" (1950) - ou o famoso "Epígrafe para a Arte de Furtar:" "roubam-me a Pátria; e a Humanidade / outros ma roubam - quem cantarei?" (1958) - ou o refrão ressonante de "Quem a tem...": "Não hei-de morrer sem saber / qual a cor da liberdade" (9.12.56) - mais o inesquecível "Uma pequenina Luz" que continua a brilhar, exata e firmemente, indefectível, quando tudo parece incerto ou falso ou violento. Luís Adriano Carlos distingue a poesia de JS pelo seu raciocínio dialético, fenomenológico e existencial (Carlos, 1999). Os versos satíricos e sarcásticos remontam a denúncias feitas por autores setecentistas como Gregório de Matos, no Brasil, e Pe. Manuel da Costa, em Portugal.

\section{Salvador, Bahia, Agosto de 1959}

Em Agosto de 1959, na ocasião do $4 .^{\circ}$ Colóquio Internacional de Estudos Luso-Brasileiros na Universidade da Bahia em Salvador, sob o patrocínio da Universidade da Bahia e da Unesco, JS aproveitou-se da oportunidade para exilar-se de Portugal e aceitar emprego como professor de literatura no Brasil. O seu exílio começou em Salvador, Bahia, para onde viajou com apenas o que levava nos braços enquanto a família, encontrando dificuldades na partida de Portugal, veio depois. O Brasil era o primeiro "porto" na grande peregrinação de JS, primeiro um posto na Universidade Estadual Paulista em Assis, depois em Araraquara. A universidade brasileira oferecia duas vantagens de interesse a JS ao deixar Portugal: colegas académicos de prestígio por onde andava e o título de professor de literatura. JS gozava, no Brasil, de colegas notáveis, entre os quais o poeta português Adolfo Casais Monteiro (1908-1972), amigo também exilado de Portugal na mesma ocasião, assim como intelectuais brasileiros da categoria de Antônio Cândido (1918-2017), Antônio Soares Amora (1917-1999) e Segismundo Spina (1921-2012). Sena tornou-se cidadão brasileiro e escreveu no Brasil muitos dos seus livros mais importantes. 
160 Aceitou fazer traduções de romances de Hemingway e Faulkner para ajudar a sustentar a família grande. Se no Brasil ganhou prestígio como professor de literatura, respeitado por colegas brilhantes, a condição de exilado ficou como dor permanente pelo resto da sua vida, no sentido definido por Edward Said nas suas reflexões sobre o exílio ("Reflections on Exile," 2000). Said descreve a separação entre um indivíduo e sua terra como perda irreparável, tristeza e estranhamento essenciais, condição de perda terminal que marca e mina quaisquer realizações que seguem a separação. Assim, como português exilado, JS nunca se sentiu completamente em casa no Brasil, em vista da obrigação de continuar a atuar conscientemente contra o cenário político e social português.

Sena contribuiu energicamente para congressos no Brasil sobre língua e literatura nos anos 1960, importantes pelos debates críticos sobre o futuro da escrita e da teoria literária no Brasil e também pela presença de estudiosos e intelectuais de primeira ordem. A atuação de JS no Brasil, após 1959, faz lembrar a produção de missões científicas e culturais europeias ao Brasil: colecionar flora e fauna, investigar o mundo material e também o mundo da natureza humana, as culturas indígenas, a psicologia e organização sociopolítica. Os seis anos passados no Brasil foram muito produtivos; JS escreveu a história da literatura inglesa e dois livros sobre Camões, Uma Canção de Camões: interpretação estrutural de uma tripla canção camoniana (1966), Os Sonetos de Camões e o Soneto Quinhentista Peninsular (1969).

\section{Exílio}

Ao sair de Portugal em 1959, JS começou um longo período de exílio, condição caracterizada por Said como descontínua, separada de suas raízes. No caso de JS, o exílio se transforma em viagem permanente descentrado, nômada, misturando passado e presente - com a consolação dos encontros com as grandes obras de arte, literatura, música e cultura nos museus e teatros do mundo, que sustentam a visão humanística e o ideal de recuperar e restaurar a grandeza da pátria perdida.

Apesar da separação geográfica e política de Portugal, JS ainda atuava, no Brasil, dentro do mundo lusófono. Considerou o próprio exílio paralelo àquele de grandes figuras históricas nas viagens de expansão e comparou a busca de verdades pessoais, por meio da poesia, às viagens dos navegadores portugueses. Da mesma maneira, segundo se aprende de uma poesia escrita em Londres (5.2.1972), JS atravessou um

cabo de tormentas metafórico: “É tal o tão perigoso e tormentório cabo/ 
de que se morre da traição do corpo / e da traição de todos os amigos" (Poesia III, p. 230).

A sua viagem ao Brasil, e mais tarde aos EUA, constituiu para ele uma cartografia dos mundos de cultura e de sabedoria por onde passava nas suas andanças, para os quais foi a poesia que serviu sempre de roteiro e guia, um compasso apontando os pontos cardiais da aventura humana, à procura da verdade, da ciência e -- valor supremo na experiência de JS dos sonhos de liberdade, realização e plenitude. As viagens se tornavam a sua autobiografia, capturada em poesia e resumida no poema "Quem muito viu" (...):

Quem muito viu, sofreu, passou trabalhos, mágoas, humilhações, tristes surpresas; e foi traído, e foi roubado, e foi privado em extremo da justiça justa; e andou terras e gentes, conheceu os mundos e submundos; e viveu dentro de si o amor de ter criado; quem tudo leu e amou, quem tudo foi

não sabe nada, nem triunfar lhe cabe em sorte como a todos os que vivem. Apenas não viver lhe dava tudo.

Inquieto e franco, altivo e carinhoso, será sempre sem pátria. E a própria morte, quando o buscar, há de encontrá-lo morto. (Peregrinatio ad Loca Infecta, p. 50)

A metamorfose e a peregrinação eram os sinais tanto da sua observação intelectual e estética, quanto da sua crítica irrestrita da vida. Contraditoriamente, em outras terras goza de liberdade de expressão, mas, como Camões, lamenta o cativeiro simbólico: “Não me peças, ó vida, o que não dás. / Se o que sempre pedi nunca me deste (...)"(Peregrinatio ad Loca Infecta, p. 45).

A visão panorâmica do mundo, começada em 1959, confirma-se por um poema, "Os trabalhos e os dias," no qual JS refere o livro do poeta Hesíodo do mesmo título, de cerca de 700: "Sento-me à mesa como se a mesa fosse o mundo inteiro (...) e escrever fosse respirar (...)" (Sobre Esta Praia, p. 84). Voltar às viagens de descobrimento servia para realçar a universalidade das próprias viagens, renovando as críticas que Camões dirigia a Portugal n'Os Lusíadas. Da mesma maneira, JS se opunha vocal e criticamente ao regime de Salazar, que atacava com sátira mordente e que 
responsabilizou por privar os cidadãos portugueses de liberdade. Com o tempo, o tema cresce em amargura e intensidade, segundo Eugénio Lisboa, a respeito de um Portugal que JS deixara atrás, e que então fomentava numa poesia de alta voltagem. Considera-se o poema de Agosto de 1971: "L'été au Portugal:" "Que esperar daqui? O que esta gente não espera porque espera sem esperar?" (Poesia-III, p. 179). Do ponto de vista oficial português daquele período, é como se JS fora deixado na costa brasileira, como os dois degredados abandonados na praia por Cabral no ano 1500 (A carta de Pero Vaz de Caminha, 1999). Para JS, liberto de outro tipo de degredo e privação, o exílio, embora penoso, era condição necessária e inevitável para poder cantar os ideais de liberdade pessoal e nacional. Seria o exílio, pois, que iria definir a existência de JS; nunca mais voltaria a morar na sua casa na R. Dinis Dias, 18 , Restelo e só depois de uma década conseguiria visitar o país brevemente, durante o governo de Marcelo Caetano.

Mesmo hoje, na data do centenário do seu nascimento, Portugal não sabe precisamente o que fazer dessa figura, bússola e voz de denúncia gigantesca, onipresente. É evidentemente um homem culto, erudito, complexo e distante de Portugal. É polifacetado nos géneros literários e poliédrico na argumentação de sua vasta obra crítica. É escritor de ensaios, com as longas introduções eruditas às edições comentadas de Faria e Sousa sobre Camões (Lusíadas de Luís de Camões, 1972; Rimas várias de Luís de Camões, 1972) ou à poesia inglesa de Fernando Pessoa (Poemas Ingleses de Fernando Pessoa, 1974), contos (o celebrado "Físico prodigioso"), um romance (Sinais de Fogo, considerado um dos mais importantes do século), teatro ( $O$ Indesejado, uma das peças mais importantes do teatro português do século $X X$ ), poesia (com Sophia, o poeta mais importante da segunda metade do século), correspondência (ainda em vias de publicar), tradutor de Hemingway, Faulkner, Kavafis e Malraux, organizador da antologia Poesia de 26 Séculos (antologia, tradução, prefácio e notas de Jorge de Sena, 1971-72). Taxando-o de "gigante indigesto da cultura portuguesa" na imprensa, Luís Miguel Queriós explicava que não existia nenhuma figura intelectual comparável desde Fernando Pessoa (Queirós, 2019). O trabalho de JS abrange cada género da criação literária, também teoria e crítica, história da cultura, qualquer um dos quais seria o suficiente para uma carreira, como nos casos dos ensaios sobre Pessoa e Camões. Agora 40 anos depois da sua morte, Queriós afirma que JS "[...] truculento e humaníssimo Minotauro das letras continua por domar." Como testemunha a sua reputação em 2019, a companhia aérea de Portugal, TAP, dedicou a aeronave mais nova a "Jorge de Sena," e os Correios de 
Portugal lançaram uma série de selos comemorativos, por $0,53 €$, um com a sua imagem e nome, "Jorge de Sena" (Os outros homenageados na série são Sophia de Mello Breyner Andresen, Fontes Pereira de Melo, Gago Coutinho, Francisco de Lacerda, Fernando Namora e Joel Serrão).

\section{Outras viagens e outros navegadores}

Em 1965 JS mudou-se para Madison, Wisconsin, nomeado catedrático no Departamento de Espanhol \& Português na Universidade de Wisconsin, para onde fora convidado por investigadores e professores hispânicos distintos; e em 1970 JS mudou-se novamente, deixando Wisconsin para Santa Barbara e UCSB, novamente encontrando-se na companhia de notáveis estudiosos e com a dupla carga de chefe de dois departamentos, Literatura Comparada de Espanhol e Português. Embora gostasse de observar que nos EUA pela lei voltava a ser cidadão português, a recuperação da sua cidadania portuguesa estava longe de ser convite ou direito de voltar a Portugal, mas era sempre um motivo de renovação e reafirmação que deu sentido aos anos de exílio e de protesto, assim como à sua imensa obra.

JS entendeu o exílio numa dimensão histórica, como o inverso de outras viagens celebradas de aventura e descobrimento. A coleção de poemas de 1969, Peregrinatio ad loca infecta, com o título em latim, evoca o pouco conhecido título oposto, o Peregrinatio ad loca sancta, ou Itinerarium Egeriae (De itinerario Aetheriae abbatissae perperam nomini s. Silviae addict ad veniam legend a summon philosoporum ordine impetrandam disputavia, Bonnae, typis Caroli Georgi typographi aademici, 1909), um texto escrito durante uma longa permanência em Jerusalém na década de 380 , ostensivamente obra de uma mulher chamada Aetheria, cujo texto foi descoberto apenas em fragmentos no século XI. Como Aetheria, JS juntou-se a uma cruzada para voltar a uma terra santa, que ao contrário de Jerusalém, porém, caracteriza como infecta, inacabada, incompleta ou falha. O título em latim confirma a intenção de espelhar o título do manuscrito de Aetheria, ao substituir o angélico pelo demoníaco.

Sena comparou o seu exílio de Portugal ao de Camões, colocando-se numa posição paralela nos poemas "Camões na Ilha de Moçambique" ou "Camões dirige-se aos seus contemporâneos" (11.06.1961):

"Podereis roubar-me tudo: as ideias, as palavras, as imagens, e também as metáforas, os temas, os motivos, os símbolos, e a primazia nas dores sofridas de uma língua nova [...] E podereis depois não me citar, suprimir-me, ignorar-me (...) Não importa nada: que o castigo será terrível 
Esses poemas andam na terra comum do exílio, sendo que Camões escolheu viajar à Índia para não ficar preso em Portugal, deixando para trás a pessoa que mais amava, para navegar no Oceano Índico e nos mares da China na qualidade de soldado, poeta, às vezes prisioneiro e funcionário público por dezassete anos na Ásia Portuguesa. As críticas agudas aos excessos e à imoralidade da aristocracia portuguesa na expansão de além-mar, tema da poesia e das cartas, ressoam nas denúncias feitas por JS a um Portugal fascista.

A segunda referência do título Peregrinatio é ao romance de viagens de Fernão Mendes Pinto, em que o cronista relata as suas aventuras peripatéticas por terras e mares asiáticos na segunda metade do século dezasseis, com o título de Peregrinação (1614) quando publicado postumamente em Lisboa pela Casa Pia de Mulheres Penitentes com o subtítulo:

Em qve da conta de mvytas e mvyto estranhas cousas que vio \& ouuio no reyno da China, no da Tartaria, no do Sornau, que vulgarmente se chama Sião, no do Calaminhan, no de Pegu, no de Martauão \& em outros muytos reynos \& senhorios das partes Orientais, de que nestas nossas do Occidente ha muyto pouco ou nenhua notícia.

Com histórias de aventuras inacreditáveis nos mares do Sul e Sudeste da Ásia, na China e no Japão, a Peregrinação logo se tornou um dos livros mais populares do seu tempo, rival do celebrado romance espanhol, o Quixote. A narração é certamente novelesca, a tendência para a hipérbole levou gerações de leitores a descontar as aventuras por falsas ou fabricações. Mesmo assim, a estudiosa Rebecca Catz, na esplêndida tradução da Peregrinação para o inglês (The Travels of Mendez Pinto, 1985), com pesquisa minuciosa confirmou os nomes e lugares geográficos mencionados no texto, apoiando a tese da verossimilhança das aventuras extraordinárias de Mendes Pinto. O trabalho de Catz teve continuação nas mãos do pesquisador galego Afonso Xavier Canosa, que publica desde 2013 sobre coordenadas e georreferências do romance (Xavier Canosa, 2013). Em 1949 o inglês Maurice Collis apresentou e traduziu segmentos da obra em tradução para o inglês (Grand Peregrination, being the life and adventures of Fernão Mendes Pinto, 1949). 
Na grande peregrinação de JS, da mesma maneira, não faltaram drama e amplitude. Uns 400 anos depois de Mendes Pinto, JS começou a narrativa poética de suas andanças pessoais, intelectuais e estéticas no exílio, como um Uliyssiponensis moderno, navegando à procura de uma pátria. No estudo "Jorge de Sena e a peregrinação no tempo" (2010), Patrícia da Silva Cardoso encontra outra dimensão do exílio nos Estudos de história e de cultura (Lisboa, 1963-67), sendo um relato detalhado da história de Portugal desde Afonso Henriques, fundador no século 12, a Philippa de Lancastre, Inês de Castro, o historiador Fernão Lopes, D Sebastião e os autores seiscentistas António Ferreira e Camões. São essas as figuras simbólicas, históricas e míticas com que se constrói uma filosofia da história de Portugal e às quais JS compara a sua situação. Guiado por contemplação, o poema (27.11.1962) que descreve a nave de Alcobaça, e o túmulo de Inês, comunica a esperança inerente a uma linha ininterrupta de história genealógica e humana:

Vazia, vertical, de pedra branca e fria / longa de luz e linhas, do silêncio / a arcada sucessiva, madrugada / mortal da eternidade, vácuo puro / do espaço preenchido, pontiaguda / como se transparência cristalina / dos céus harmónicos, espessa, côncava / de rectas concreção, ar retirado ao tremor último da carne viva (...) geometria / do espírito provável (...) Esperança / vazia e vertical. Humanidade ("A Nave de Alcobaça," Poesia-II, p. 83)

A peregrinação de JS foi prolífica, sem ser fantástica ou mágica. Era uma fuga face à impossibilidade de voltar a Portugal. JS não viajava por mundos desconhecidos, mas é como se fosse condenado a viajar eternamente pelos mares do mundo, feito fantasma, um holandês voador. Mesmo depois da Revolução dos Cravos de 1974, um período de instabilidade política, até caótico, tornou imprudente qualquer tentativa de voltar. Logo se manifestaram as doenças que levariam JS à morte dentro de apenas mais quatro anos. Foi em Santa Barbara em Abril de 1978 que falou comigo dos planos de voltar à Europa em Novembro, com a ressalva, "se for vivo."

\section{Cartografia do exílio}

O mapeamento da grande peregrinação de JS encontra-se nos livros de poesia após 1959, constituindo uma biografia intelectual de variações no tema de estar-se no mundo. A partir dessa data, a poesia JS se dedica ao relato de uma viagem intelectual e global, pressentida no poema "Post-Scriptum" (1954), no qual escreve que a poesia é um disfarce da realidade ("(...) aquel' que aceita suspeitar / quanto mesmo a poesia ainda 
é disfarce da vida"). Segue Metamorfoses (1963), acompanhado pelos sonetos experimentais Quatro Sonetos a Afrodite Anadiómina, a Arte de Música (1968) e Peregrinatio ad Loca Infecta (1969), onde proclama que, embora certamente morrerá exilado, manter-se-á fiel ao mundo da língua portuguesa e a um Portugal restaurado à justiça e à liberdade. O livro Exorcismos (1972) começa com o aviso, "Não leiam delicados este livro," pois JS confessa "a dor de haver nascido em Portugal, sem mais remédio que trazê-lo na alma" ("Aviso à porta de livraria", de 25.01.1972, Poesia III, p. 178). Seguem os últimos dois livros, o celebrado Camões Dirige-se aos seus Contemporâneos (1973) e a última meditação, escrita em Santa Bárbara, Califórnia, Sobre Esta Praia (1977).

Traçar um mapa da grande peregrinação poética de JS começa com um paradoxo barroquista, a sua exclusão do mundo, estando no mundo, situação capturada na descrição por ele mesmo, quase autobiográfica do exílio na poesia:

Porque não espero de jamais voltar / à terra em que nasci; porque não espero / ainda que volte, de encontra-la pronta / a conhecer-me como agora sei / que eu a conheço ("Glosa de Guido Cavalcanti," de 11.06.1961, Poesia III, p. 53) / É impossível discutir seja o que for / Se se tem razão, ou não tem / é totalmente indiferente: / ou se aceitam as regras do jogo, ou se muda de vida e de lugar ("É impossível discutir", Sequências, p. 102) / Quem muito viu, sofreu, passou trabalhos, mágoas, humilhações, tristes surpresas e foi traído e foi roubado, e foi privado de justiça justa / e andou terras e gentes, conheceu os mundos e submundos; e viveu / dentro de si o amor de ter criado (...) será sempre sem pátria ("Quem muito viu," Poesia III, p. 50) / Nem Deus, nem pátria, nem amor, nem vida (...) resta o nome solitário (...) Mas que esperança tive alguma vez, que desespero tive, mesmo tênue à transparência de que nada vi? E para quê? Se tudo é só traição, se tudo existe e sucede assim (...) Oh Insensata busca. Ingenuidade ("Heptarquia do mundo ocidental," Poesia III, p. 41) / Hoje não há mais mundo / de que uma pessoa pode retirar-se / O mundo se retirou de nós (...) e a solidão é como um convento gigantesco ("Glosa de Guido Cavalcanti," Poesia III, p. 53).

A segunda coordenada no mapa do exílio é formada por juízo moral e justiça, armas dirigidas pelo poeta ao mundo do grande império marítimo:

[...] ladrões / promíscuos, bestiais / traiçoeiros, sádicos / belíssimos às vezes, ("Homenagem à Grécia," Poesia III, 47) / o pensamento arguto penetrando as coisas / o sofrimento e o amor" ("A Máscara do Poeta," Poesia 1, 351-53) / O mundo é um imenso cais de intolerância austera / a que aportam escravos, pimento" ("Eleonora de Toledo," Poesia II, pp. 101-104) / Morrem jovens os que os deuses amam, dizia o poeta. 
E eu pergunto: morrem velhos os que eles detestam?" ("Glosa de Menandro," Poesia III, p. 58) / "Roer um osso - humano se possível, / é o sonho português de sobrevida / após anos e anos de despirem / com os olhos as mulheres ("Balada do Roer dos Ossos," Poesia III, p. 178).

JS junta juízo moral a sátira política. Ao comentar a composição patriótica do tcheco Bedřich Smetana, "Ma Vlast," Sena questiona, "Para amar uma pátria assim (...) será que ela seja escrava (...) de um passado glorioso (...) não brotam pátrias puras" ("Ma Vlast de Smetana," Poesia II, p. 199). O poema "A Portugal" expressa sentimentos totalmente opostos aos do Smetana: "Esta é a ditosa pátria minha amada. Não. / Nem é ditosa, porque o não merece / Nem minha amada, porque é só madrasta / Nem pátria minha, porque eu não mereço / A pouco sorte de nascido nela" ("A Portugal," 40 Anos de Servidão, p. 89).

Ao mesmo tempo, a sátira que dirige à política brasileira, na "Valsa da Democracia," precede o discutido "Poema Sujo" (1976), de Ferreira Gullar e o conhecido poema de Affonso Romano de Santana, "Que país é este?" (1980) pela denúncia sutil e perspicaz: "Este é um pergaminho encadernado noutro, com fecho de ouro e cadeado de prata, e dentro, ao abrir-se, uma bailarina, à vista, e uma caixa de música, oculta, ao som da qual a bailarina dança / a Valsa da Democracia" (Poesia, vol. 2, pp. 536-38).

O mapa do exílio de JS é também composto de mares e terras interiores. Traça a sua condição existencial e avalia a possibilidade de esperança, inspirado numa cantiga de amor da lírica medieval: "nas terras de além do mar, / está meu Amor assentado / Seus olhos fitam a noite/ seu seio sobressaltado / Oh minha dama da amargura" ("Nas terras de Além do Mar" Poesia 2, p. 531). A existência se torna solidão num mundo de exílio: "nada nos livra de nós mesmos" ("Cabecinha Romana de Milreu," Poesia II, p. 69); a inteligência (...) busca ad infinitum combinações possíveis bem que ilimitadas ("Bach Variações Goldberg," Poesia II, p. 176); Na sem-razão de que vivemos todos / sonhando sermos mais humanos que ontem" ("For Whom the Bell Tolls," Poesia, vol. 1, pp. 510-514). Para JS, viajando no exílio, o tempo se converte em distância: "Há uma distância incomensurável entre nós. E dir-se-ia que nenhum gesto é bastante para os atingir" ("Soneto do Envelhecer," 40 Anos de Servidão, p. 163); "Neste desespero ansioso de que o tempo dure / um pouco mais, não corra tanto, se não escape / não por entre os dedos, mas através da própria forma das coisas" ("Elegia por Certo," Poesia, vol. 2, pp. 564-567); Ouço-te, ó música, chegar desnuda / ao vácuo centro (...) além da forma e do conceito / além do que transforma / contrários pares" ("Requiem, de Mozart," Poesia-II, p. 185). 
Não obstante o constante viajar, como Camões e outros navegadores seiscentistas nos mares do império, JS retém a esperança neobarroca de achar ou realizar o grande significado da vida, com reintegração na pátria e salvação da condição extrema de exilado furibundo:

Amor, saudades tenho desta vida / Por mais que a viva ou a deteste, ou ranja / de raiva os dentes por não estar saciado do que ela mais recusa a quem deseja mais ("Amor, Saudades Tenho, Poesia, vol. 1, p. 674) / Não foi para morrer que nós nascemos / que falamos / que sonhamos / Nós somos o que nega a natureza / Não há limites para a Vida ("A Morte, Espaço, Eternidade," Poesia II, p. 137); Não posso desesperar da humanidade. E como gostaria de! / se mesmo eu amo sobretudo o vário mundo ("Não Posso Desesperar da Humanidade," 40 Anos de Servidão, p. 103); De pouco me contentaria / Verdade. / Paz. / Justiça / e Liberdade (“Sobre as Metáforas," Poesia, vol. 2, p. 567).

\section{Viajante mundial}

JS aprende a viajar na poesia e a viver pela cultura e sabedoria. Por meio das excursões enciclopédicas e museológicas por cultural mundiais, elabora uma visão humanística e universalista, aplicando as lições do iluminismo europeu ao momento contemporâneo. Como para provar a sua universalidade, JS compila uma antologia da poesia de 26 séculos, em dois volumes, traduzida para o português; organiza e escreve um prefácio extensivo para uma antologia da poesia portuguesa, o volume das Líricas Portuguesas; traduz Cavafy e Dickinson. Nos livros de poesia posteriores a 1960 - Metamorfoses, Arte de Música, Peregrinatio ad loca infecta, Exorcismos - JS viaja livremente pela arte, música e literatura. Nas Metamorfoses JS revisita a Ibéria e a cultura do mediterrâneo - a Mesquita de Córdoba, o Mosteiro de Alcobaça, a Pietà de Avignon, a Granduchessa di Toscana - e poetiza à base de obras de Rembrandt, Fragonard, Turner, Van Gogh, Keats e Goya.

A música é outra dimensão da sua liberdade, porque os compositores não são limitados pela palavra: "Não é, portanto, a música o limite / ilimitado dos limites da linguagem,/ para dizer-se o que não é dizível?" ("Ouvindo o Quarteto Op. 131, de Beethoven," Poesia-II, pp. 188-190). Na Arte de Música (1968) JS evoca uma série de compositores, do renascimento ao século 20: Dowland, Bach, Händel, Scarlatti, Mozart, Beethoven, Berlioz, Chopin, Schumann, Liszt, Wagner, Brückner, Brahms, Smetana, Mussorgsky, Tchaikovsky, Puccini, Mahler, Strauss, Debussy, Sibelius, Satie, Bartok, Schönberg e Piaf (tema do estudo fundamental de Francisco Cota Fagundes, A poet's way with music: humanism in 
Jorge de Sena's poetry, 1988). O mapeamento das culturas mundiais concentra-se na Europa, depois das viagens de regresso de 1969 e 1972, quando também visita Moçambique. O volume Exorcismos apresenta um panorama das cidades europeias e suas culturas literárias, desde Copenhague a Spinoza em Amsterdão, a Düsseldorf, Viena, Milan, Roma e Florença, a Salamanca e Santiago de Compostela, ao Prado, a Paris, Antuérpia, Londres, Edimburgo e Glasgow. Na última poesia geográfica de JS, no ano anterior à morte, Sobre Esta Praia: Oito Meditações à Beira do Pacífico (1977), escrito em Santa Bárbara, há outra virada, para um último e definitivo regresso à filosofia humanística, com outro porto, substituto, de chegada: "Aqui é um outro oceano (...) um outro tempo [...] Se aqui nasceram deuses, nada resta deles" (Poesia III, p. 241) / "a calma e tamisada serena paz de tardes infinitas" (Sobre Esta Praia III) / "Mas hoje só memória. E é tarde já, no dia como no ano, até que voltem mais do que manhãs de sucessivas em continua série bastante a despertar o gosto habituado em estios que hoje súbitos se acabam" (Sobre Esta Praia IV) /, "neste país onde a vida esconde de todos e si mesma até um gesto vago em que de alguém a natureza espreite (...)" (Sobre Esta Praia V).

O poema "Em Creta, com o Minotauro" (1965) retoma a grande peregrinação de JS pelo mundo pré-clássico e pelas culturas da humanidade; representa a sua autobiografia, num poema que reduz as viagens e experiências relacionadas a elas à sua essência. Narra o poema entre um tom épico, confessional, pedagógico e coloquial: "O Minotauro compreender-me-á, tomará café comigo, enquanto o sol serenamente desce sobre o mar" (Poesia III, p. 76). Com o Minotauro, JS volta às origens da cultura, antes da história, da língua e antes de Portugal. Conversam em "volapuque," ou em língua alguma e país algum: "Nem eu, nem o Minotauro, teremos nenhuma pátria. Apenas o café, aromático e bem forte, não da Arábia ou do Brasil [...] ou de Angola, ou parte alguma. Mas café / contudo" (Poesia III, p. 77). O encontro com o Minotauro representa a procura de uma visão utópica ou redentora, uma solução para o estarno-mundo. Ao escrever "Eu sou eu mesmo a minha pátria" (Poesia III, p. 76), JS confirma uma identidade construída por uma consciência ética e talvez pela linguística genealógica, mas principalmente por um respeito profundo pela vida, quando "não acredito em outro, e só outro quereria que este mesmo fosse."

JS se senta para tomar café como o Minotauro para discutir as origens da vida e afirmar os seus maiores valores. "Em Creta" é o poema que supera a profunda desilusão do exílio político; como a "pequenina luz" que nunca se apaga, afirma a fé sem limite do poeta na nossa comum humanidade. 
O café aromático é ao mesmo tempo uma conciliação, uma nova pátria, a fantasia idílica de um reencontro com as origens da verdade: "Em Creta, com o Minotauro (...) hei-de tomar em paz o meu café" (Poesia III, p. 78). Foi em Santa Barbara que a grande peregrinação de JS chegou ao seu grande encerramento e final.

Santa Barbara, Califórnia, 16 de Novembro de 2019

\section{Bibliografia}

Cardoso, P. da S. (2010). "Jorge de Sena e a peregrinação no tempo." Comunicação no Congresso Internacional da Cátedra Jorge de Sena, UFRJ.

Carlos, L. A. (1999). Fenomenologia do discurso poético: ensaio sobre Jorge de Sena. Porto: Campo das Letras.

Carta de Pero Vaz de Caminha. (1999). A. Ericeira, Mar de Letras.

Carvalho, J. V. de (2019). Jornal de Letras, 1280, 10.

Collis, M. (1949). Grand Peregrination: being the life and adventures of Fernão Mendes Pinto. London: Faber \& Faber.

Cortez, A. C. (2019). Jornal de Letras, 1280 , 7-10.

Itinerarium Egeriae. Latim \& Francês. Journal de voyage, 1982: t. p.; The Pilgrimage of Etheria. London: Society for Promoting Christian Knowledge, 1919.

Fagundes, F. C. (1988). A poet's way with music: humanism in Jorge de Sena's poetry. Providence, R.I.: Gávea-Brown.
Pinto, F. M. (1985). Peregrinacam, Lisboa: Pedro Crasbeeck, 1614; Travels of Mendes Pinto, trad. e notas Rebecca Catz. Chicago: University of Chicago Press.

IV Colóquio Internacional de Estudos LusoBrasileiros. (1959). Salvador, Bahia: Imprensa Oficial da Bahia.

Queirós, L. M (2019). “Jorge de Sena: o gigante indigesto da cultura portuguesa." ípsilon, 15-16.

Said, E. (2000). "Reflections on Exile." Reflections on exile and other literary and cultural essays (pp. 137-149). Cambridge: Harvard University Press.

Xavier Canosa, A. (2013). "Referentes por coordenadas e georreferências relativas das entidades geográficas mencionadas na Peregrinação." Veredas: Revista da Associação Internacional de Lusitanistas, 9-34. 


\section{Obras selectas de Jorge de Sena}

Poesia:

Perseguição. Lisboa: Edições Cadernos de Poesia, 1942.

Coroa da Terra. Porto: Lello \& Irmão, 1946.

Pedra Filosofal. Lisboa: Editorial

Confluência limitada, 1950.

As Evidências. Poema em Vinte e Um Sonetos. Lisboa: Centro Bibliográfico, 1955. Fidelidade. Lisboa: Livraria Morais Editora, 1958.

Metamorfoses, seguidas de Quatro Sonetos a Afrodite Anadiómena. Lisboa: Libraria Morais Editora, 1963.

Arte de Música. Lisboa: Moraes Editores, 1968.

Peregrinatio ad Loca Infecta. Lisboa: Portugália Editora, 1969.

Exorcismos. Lisboa: Moraes Editores, 1972.

Camões Dirige-se aos Seus

Contemporâneos e Outros Textos. Porto: Editorial Inova, 1973.

Conheço o Sal ... e Outros Poemas. Lisboa: Moraes Editores, 1974.

Sobre Esta Praia ... Oito Meditações à beira do Pacífico. Porto: Editorial Inova, 1977.

\section{Coleções:}

Poesia I. Lisboa: Moraes Editora, 1977.

Poesia. Jorge Fazenda Lourenço, ed. 2 vols. Lisboa: Guimarães, 2015.

Poesia II. Lisboa: Moraes Editora, 1978

Poesia III. Lisboa: Moraes Editora, 1978

40 Anos de Servidão. Lisboa: Moraes, 1982.

Sequências. Lisboa: Moraes Editora, 1980

\section{Antologias:}

Líricas Portuguesas: $3^{a}$ Série. Selecção, prefácio e notas. Lisboa: Portugália Editora, 1958.

Poesia de 26 Séculos 2 vols.: I - De Arquíloco a Calderón; II - De Bashó a Nietzsche. Tradução, prefácio e notas. Porta: Editorial Inova, 1971, 1972.

\section{Prefácios e Introduções:}

Lusíadas de Luís de Camões, comentadas por Manuel de Faria e Sousa, Introdução de Jorge de Sena, Lisboa, Imprensa Nacional, 1972.

Poemas Ingleses de Fernando Pessoa. Edição bilíngue, com prefácio, traduções, variantes e notas de Jorge de Sena. Lisboa: Edições Ática, 1974.

Rimas várias de Luís de Camões, comentadas por Manuel de Faria e Sousa, nota introdutória do F. Rebelo Gonçalves, prefácio de Jorge de Sena, Lisboa, Imprensa Nacional-Casa da Moeda, 1972

\section{Traduções:}

90 e Mais Quatro Poemas de Constantinos $P$. Cavafy. Tradução, prefácio, comentários e notas. Porta: Editorial Inova, 1970.

80 Poemas de Emily Dickinson. Tradução e apresentação. Ed. Mécia de Sena. Lisboa: Edições 70, 1979.

\section{Ensaios e Crítica:}

Uma Canção de Camões: interpretação estrutural de uma tripla canção camoniana. Lisboa: Portugália, 1966.

A Literatura Inglesa: Ensaio de Interpretação e de História. São Paulo: Editora Cultrix, 1963.

Estudos de História e de Cultura (1a Série). Vol. 1. Lisboa: Ocidente, 1967.

Os Sonetos de Camões e o Soneto Quinhentista Peninsular. Lisboa: Portugália, 1969.

Trinta Anos de Camões, 1948-1978 (Estudos Camonianos e Correlatos). 2 vols. ed. Mécia de Sena. Lisboa: Edições 70, 1980.

\section{Teatro:}

O Indesejado (António, Rei). Porto: Portvcale, 1951.

\section{Prosa de ficção:}

O Físico Prodigioso (novela). Lisboa: Edições 70, 1977

Sinais de Fogo (novela). Ed. Mécia de Sena. Lisboa: Edições 70, 1979. 